\title{
ANALISIS PRESEPSI MAHASISWA TERHADAP PERILAKU KORUPSI (STUDI KASUS MAHASISWA STIE-I RENGAT)
}

\author{
Oleh: \\ YUSNEDI \\ Program Studi Manajemen Sekolah Tinggi Ilmu Ekonomi Indragiri (STIE-I) Rengat \\ E-mail : yusnedi@stieindragiri.ac.id
}

\begin{abstract}
Abstrak
Banyak faktor yang menghambat program pemberantasan korupsi di Indoneeia, salah satunya adalah sikap hipokrisi (mendua-munafik); sikap yang pertama korupsi dihujat dan sikap yang kedua perilaku korupsi dianggap bagian dari budaya yang tidak bisa lepas dari perilaku sehari-hari. Dari data penelitian yang diambil melalui kuesioner pada 44 orang mahasiswa semester 6 Tahun akademik 2017/2018, menjelaskan bahwa perilaku korupsi yang dilakukan oleh pihak-pihak yang terkait dengan mereka dianggap sebagai hal yang negatif, namun sebaliknya jika ada keterkaitan dengan dirinya, mahasiswa cendrung memberikan toleransi. Mahasiswa secara umum tidak melakukan korupsi terhadap uang Negara, tetapi mahasiswa sering melakukan pelanggaran terhadap kepercayaan yang diberikan kepada mereka, sehingga jika analogkan mahasiswa juga berpotensi melakukan korupsi seperti yang dilakukan oleh pejabat Publik. Dan salah satu cara untuk mencegah terjadinya korupsi dikalangan generasi muda dengan mengevaluasi pendidikan moral dengan kolaborasi dengan pendidikan anti korupsi.
\end{abstract}

Kata Kunci : Presepsi Mahasiswa, Perilaku Korupsi

\section{PENDAHULUAN}

Pendidikan Karakter di Indonesia disebabkan oleh kemerosotan moral bangsa, salah satu akibatnya adalah maraknya kasus korupsi di tanh air. Lembaga Transparansi Internasional, meprediksikan Indonesia 5 tahun kedepan masih menduduki indeks persepsi korupsi 2,8 pada skala 0 sampai 10 dan peringkat keempat (ke-4) sebagai Negara paling korup di Asia (metrotvnews.com, Sabtu, 30 Juli 2017). Kampus sebagai lembaga akademik yang diharapkan wadah pembentukan karakter generasi muda ternyata tidak bersih dari perilaku korupsi. Ini terbukti sekurang-kurangnya ada lima perguruan tinggi di Indoesia dinyatakan bersalah dan patut diduga terlibat dalam korupsi (Tribunnews.com, Selasa, 6 Maret 2017).

Beberapa upaya untuk memberantas korupsi di Indoesia sudah dilaksanakan, mulai dari penandatangan nota kesepahaman (MoU) Menteri pendidikan dengan Komisi Pembrantasan Korupsi dalam bentuk kerjasama pemberantasan korupsi dan salah satu bentunya penerapan pendidikan antikorupsi mulai dari SD, SMP, SMA sampai ke Perguruan Tinggi. Hal terjadi sebagai reaksi kekecewaan masyarakat dan tokoh bangsa atas kegagalan pendidikan agama dalam membentuk akhlak individu yang bertakwa. 
Sikap terhadap korupsi adalah vaiabel yang signifikan dalam menentukan perilaku korupsi itu sendiri. Menurut Tanzi dan Treisman ( dalam Rabl, 2005) Perilaku korupsi diawali dengan adanya keiinginan, Keinginan untuk melakukan perbuatan korup akan menjadi lebih kuat bila pelakunya memiliki sikap yang positif atau menyetujui korupsi, serta bila orang-orang yang dianggap penting oleh pelaku juga menerima korupsi sebagai perilaku yang disetujui; selanjutnya keinginan itu akan bertransformasi menjadi komitmen untuk bertindak korup, dan intenspun terbentuk (Heckhausen, dalam Rabl, 2011).

Dalam bahasa hukum membatasi definisi korupsi sebagai penyalahgunaan wewenang yang dilakukan oleh pejabat publik; namun Lembaga Transparansi Internasional memperluas pengertian korupsi sebagai "penyalahgunaan kepercayaan yang diberikan oleh orang lain, untuk kepentingan pribadi" (Wijayanto, 2009). Merujuk pada ajaran Islam, korupsi adalah perbuatan melanggar amanah. Definisi dari Lembaga Transparansi Internasional juga memungkinkan setiap individu baik pejabat publik maupun anggota masyarakat biasa berpotensi melakukan korupsi.

Subjek dalam penelitian ini yang membahas presepsi terhadap perilaku korupsi ini adalah mahasiswa STIE-I Rengat dengan batas lingkup Semester 6 Tahun Ajaran 2017/2018, dengan alasan mahasiswa adalah komponen yang signifikan dalam tubuh bangsa ini. Pertama karena usia yang muda, berarti para mahasiswa itulah masa depan bangsa ini. Kedua, sebagai kaum terdidik, mahasiswa berpotensi menjadi calon pemimpin yang memegang kendali bangsa ini di masa depan. Di sisi yang lain, pendidikan yang telah ditempuh para mahasiswa juga perlu dievaluasi. Apakah pendidikan selama bertahun-tahun itu berhasil membentuk karakter mahasiswa menjadi individu yang amanah dan pantang korupsi, atau sebaliknya?

Tujuan dari penelitian ini diharapkan dapat memberikan kontribusi memberikan "hadiah" sebagai tanda terima kasih pada orang yang berjasa memperlancar urusan di salah satu kantor pemerintah. Perilaku menyuap aparat berbentuk pemberian uang damai pada polisi lalu lintas, sedangkan perilaku korup dalam konteks akademik adalah: saling memberi contekan waktu ujian, dalam mengevaluasi sistem pendidikan akhlak di Indonesia, serta memberikan saran bagi perbaikan pendidikan selanjutnya, baik yang sudah ada seperti pendidikan agama, kewarganegaraan, serta pendidikan karakter, maupun yang baru diterapkan seperti pendidikan anti korupsi

\section{LANDASAN TEORI}

\section{A. Presepsi}

Persepsi merupakan salah satu aspek psikologis yang penting bagi manusia dalam merespon kehadiran berbagai aspek dan gejala di sekitarnya.Persepsi mengandung pengertian yang sangat luas, menyangkut intern dan ekstern. Berbagai ahli telah memberikan definisi yang beragam tentang persepsi, walaupun pada prinsipnya mengandung makna yang sama.

Menurut Kamus Besar Bahasa Indonesia, persepsi adalah tanggapan (penerimaan)langsung dari sesuatu. Proses seseorang mengetahui beberapa hal melalui panca inderanya. Sugihartono, dkk (2007: 8) mengemukakan bahwa persepsi adalah kemampuan otak dalam menerjemahkan stimulus atau proses untuk menerjemahkan stimulus yang masuk ke dalam alat indera manusia. Persepsi manusia terdapat perbedaan sudut pandang dalam penginderaan. 
Ada yang mempersepsikan sesuatu itu baik atau persepsi yang positif maupun persepsi negatif yang akan mempengaruhi tindakan manusia yang tampak atau nyata. Bimo Walgito (2004: 70) mengungkapkan bahwa persepsi merupakan suatu proses pengorganisasian, penginterpretasian terhadap stimulus yang diterima oleh organisme atau individu sehingga menjadi sesuatu yang berarti, dan merupakan aktivitas yang integrated dalam diri individu. Respon sebagai akibat dari persepsi dapat diambil oleh individu dengan berbagai macam bentuk. Stimulus mana yang akan mendapat kanrespon dari individutergantung pada perhatian individu yang bersangkutan.

\section{B. Perilaku}

Perilaku manusia merupakan seluruh kegiatan yang dilakukan oleh manusia, baik dilihat secara tidak langsung maupun langsung oleh pihak luar (Notoatmodjo, 2010).

Perilaku adalah segenap manifestasi hayati individu dalam berinteraksi dengan lingkungan, mulai dari perilaku yang paling nampak sampai yang tidak tampak, dari yang dirasakan sampai paling yang tidak dirasakan (Okviana, 2015).

\section{Korupsi}

Korupsi berasal dari bahasa Latin: corruption dari kata kerja corrumpereberarti busuk, rusak, menggoyahkan, memutarbalik, menyogok. Menurut TransparencyInternationaladalah perilaku pejabat publik, baik politikus/politisi maupun pegawai negeri, yang secara tidak wajar dan tidak legal memperkaya diri atau memperkaya mereka yang dekat dengannya, dengan menyalahgunakan kekuasaan publikyang dipercayakan kepada mereka.

Sedangkan dalam Kamus Besar Bahasa Indonesia, korupsi secara harfiah berarti: buruk, rusak, suka memakai barang (uang) yang dipercayakan padanya, dapat disogok (melalui kekuasaannya untuk kepentingan pribadi). Dalam arti terminologinya, korupsi adalah penyelewengan atau penggelapan (uang negara atau perusahaan) untuk kepentingan pribadi atau orang lain

\section{METODE PENELITIAN}

Penelitian ini didasarkan atas data dari studi eksploratif yang memanfaatkan gabungan antara pendekatan kuantitatif dan kualitatif. Data diambil dengan metode kuesioner dan wawancara Kuesioner diberikan kepada 44 orang mahasiswa semester 6 tahun akademik 2017/2018 Sekolah Tinggi Ilmu Ekonomi Indragiri (STIE-I) Rengat Tujuannya untuk mengungkapkan presepsi mahasiswa terhadap perilaku korupsi yang terdiri atas penyalahgunaan wewenang, perilaku memberi dukungan terhadap penyalahgunaan wewenang, perilaku menyuap aparat lalulintas, serta perilaku korup dalam konteks kegiatan akademik.

Penyalahgunaan wewenang terdiri atas ASN yang melakukan korupsi, penyalahgunaan jabatan anggota DPR atau pejabat pemerintah, serta memanfaatkan pengaruh seseorang supaya anggota keluarga/kerabat diterima sebagai ASN.

Perilaku mahasiswa mencontek beberapa kalimat dari internet dalam pembuatan tugas makalah, serta menjiplak sebuah artikel internet secara utuh. Subjek diminta memutuskan satu dari dua respon sikap yaitu menganggap bentuk perilaku tersebut 
memalukan, atau menganggapnya lumrah/wajar. Data dari kuesioner dianalisa dengan tabel frekuensi dan persentase.

\section{HASIL PENELITIAN DAN PEMBAHASAN}

Dari hasil penelitian didapatkan bahwa korupsi yang dilakukan didapat jawaban responden terhadap perilaku seperti pada tabel 1 .

Tabel 1. Jawaban Responden tentang Bentuk respon terhadap perilaku Korupsi

\begin{tabular}{|r|l|c|c|}
\hline \multirow{2}{*}{ No. } & \multicolumn{2}{|c|}{ Bentuk Respon } & \multicolumn{2}{c|}{ Jumlah Responden } \\
\cline { 3 - 4 } & & Angka (orang) & Porsentase (\%) \\
\hline 1. & Perbuatan Memalukan & 40 & \\
\hline 2. & Perbuatan biasa/wajar & 3 & \\
\hline 3. & Tidak Bersikap & 1 & \\
\hline \multicolumn{2}{|c|}{ Jumlah } & 44 & 100 \\
\hline
\end{tabular}

Hasil Wawancara, 2017

Dari tabel 1 diatas, menunjukan bahwa sikap mahasiswa terhadap perilaku korupsi yang paling menonjol adalah perbuatan memalukan, hanya 1 orang ( $1 \%$ ) yang tidak bersikap.

Sikap mahasiswa terhadap penyalagunaan jabatan yang dilakukan oleh Anggota DPRD Kabupaten Indragiri Hulu atau pejabat pejabat pemerintah dapat dijelaskan pada tabel 2.

Tabel 2. Jawaban Responden tentang perilaku Korupsi yang dilakukan oleh anggota DPRD dan Pejabat Pemerintah.

\begin{tabular}{|r|l|c|c|}
\hline \multirow{2}{*}{ No. } & \multicolumn{2}{|c|}{ Bentuk Respon } & \multicolumn{2}{c|}{ Jumlah Responden } \\
\cline { 3 - 4 } & & Angka (orang) & Porsentase (\%) \\
\hline 1. & Perbuatan Memalukan & 37 & \\
\hline 2. & Perbuatan biasa/wajar & 7 & \\
\hline 3. & Tidak Bersikap & 1 & \\
\hline \multicolumn{2}{|c|}{ Jumlah } & 44 & 100 \\
\hline
\end{tabular}

Hasil wawancara, 2017

Tabel 2 menjelaskan bahwa presepsi mahasiswa terhadap perilaku anggota DPRD dan pejabat pemerintah Kabupaten Indragiri Hulu terhadap korupsi adalah perbuatan memalukan.

Berbeda dengan presepsi mahasiswa terhadap perilaku memanfaatkan pengaruh dalam proses penerimahan CASN, lebih dari setengah mahasiswa $(54,5 \%)$ menganggapnya sebagai perbuatan yang wajar.ternyata dalam kontek ini mahasiswa bersikap lebih lunak.

Objek lain adalah wewenang untuk memprioritaskan seseorang karena kepentingan pribadi, dan bukan atas dasar profesionalitas, sesungguhnya merupakan pelanggaran atas hak orang lain (yang secara profesional lebih layak untuk mendapatkan kesempatan tersebut), sehingga dikategorikan sebagai perilaku korupsi.

Dunia Kampus yang merupakan wadah hidup mahasiswa ternyata tidak steril dari perilaku korupsi yang berbentuk saling menyontek dalam ujian dan menjiplak karya orang lain. Lebih dari separuh responden, yaitu sebesar 63,7\% menganggap saling menyontek dalam ujian adalah perbuatan yang lumrah, sisanya $36,3 \%$ menganggap menyontek itu memalukan. Menjiplak sebagian dari karya orang lain 
dinilai lumrah oleh $84,1 \%$ responden, hanya $15,9 \%$ dari mereka yang menganggapnya sebagai tindakan yang memalukan, bahkan menjiplak keseluruhan karya orang lain masih dinilai wajar oleh $31,4 \%$ responden, sementara $68,6 \%$ responden menganggapnya memalukan. Sikap mahasiswa terhadap perilaku korup dalam konteks

Perbuatan korup lain yang dilakukan oleh mahasiswa adalah mengkorupsi uang dari orang tua. Ternyata perilaku ini dinilai biasa dan membudaya di kalangan mahasiswa. Umumnya yang dikorupsi adalah uang yang digunakan untuk membayar kegiatan-kegiatan akademik seperti SPP dan sebagainya. Modusnya dengan tidak memberi tahu orang tua bahwa ada sisa dari uang pembayaran, lalu menggunakan sisa uang tersebut untuk kepentingan pribadi tanpa sepengetahuan orang tuanya.

\section{PENUTUP}

Presepsi Mahasiswa terhadap korupsi yang dilakukan oleh pihak-pihak yang tidak memiliki keterlibatan dengan dirinya sebagai hal yang negatif, tetapi bila ada keterlibatan dengan dirinya akan cenderung menoleransi.

Mahasiswa memang tidak melakukan tindakan korupsi terhadap uang negara, namun mereka melakukan pelanggaran terhadap hal yang diamanahkan padanya sehingga bila diposisikan secara setara sesungguhnya mahasiswa juga berpotensi untuk melakukan korupsi yang sama dengan yang dilakukan oleh pejabat publik.

Pendidikan moral dan Pendidkan Anti Korupsi perlu dievaluasi, karena materi yang diberikan ternyata pengaruhnya jauh lebih lemah dibandingkan dengan pengaruh lingkungan sehari-hari. Perlu ada sinergi antara teori dengan kenyataan hidup yang diamati dan dialami dalam keseharian

\section{REFERENCE}

Albarracin, D., Johnson, B. T. \& Zanna, M. P. (ed). (2005). The Handbook of Attitudes. New Jersey: Lawrence Erlbaum Associates, Inc.

Baron, R. A., Byrne, D. (2004). Psikologi Sosial. Edisi Kesepuluh Jilid 1 (terjemahan Bahasa Indonesia). Jakarta: Penerbit Erlangga.

Departemen Pendidikan dan Kebudayaan RI (1995), Kamus Besar Bahasa Indonesia, Jakarta, Balai Pustaka,

Porta, D. (2004). Political Parties and Corruption: Ten Hypotheses on Five Vicious Circles. Crime, Law \& Social Change 42, 35-60. The Netherlands: Kluwer Academic Publishers.

Rabl, T. (2011). The Impact of Situational Influences on Corruption in Organizations. Journal of Business Ethics, 100, 85-101.

Muhammad Shoim (2009), Laporan Penelitian Individual (Pengaruh Pelayanan Publik Terhadap Tingkat Korupsi pada Lembaga Peradilan diKota Semarang), Semarang, Pusat Penelitian IAIN Walisongo 
Wijayanto. (2009). Memahami Korupsi, Dalam Korupsi Mengorupsi Indonesia: Sebab, Akibat, dan Prospek Pemberantasan. Jakarta: PT Gramedia Pustaka Utama.

http://metrotvnews.com/read/newsvideo/2011/07/30/133089/Indonesia-masih-

Keempat-Terkorup-diAsia (online); diunduh pada tanggal 9 April 2012 pukul 23:53 WIB

http://www.republika.co.id/berita/pendidikan/berita-pendidikan/12/03/09/m0louxkemendikbudterapkan-kurikulum-pendidikan-antikorupsi (online); diunduh pada tanggal 10 April 2012 pukul 00:01 WIB

http://www.suaramerdeka.com/smcetak/index.php?fuseaction=beritacetak.detailberi tacetak\&id_berita cetak=180006 (online); diunduh pada tanggal 10 April 2012 pukul 04:13 WIB

http://www.tribunnews.com/2012/03/06/kpk-dalami-korupsi-kampus-universitasindonesia (online); diunduh pada tanggal 10 April 2012 pukul 01:06 WIB 